\title{
Differential Effect of Aluminium on Enzymes of Nitrogen Assimilation in Excised Bean Leaf Segments
}

\author{
Priyanka Gupta, Juliana Sarengthem, Sonal Dhamgaye, Rekha Gadre* \\ School of Biochemistry, Devi Ahilya University, Indore, India \\ Email: "rekhagadre29@gmail.com
}

Received 22 March 2016; accepted 14 June 2016; published 17 June 2016

Copyright ( 2016 by authors and Scientific Research Publishing Inc.

This work is licensed under the Creative Commons Attribution International License (CC BY). http://creativecommons.org/licenses/by/4.0/

(c) (i) Open Access

\begin{abstract}
Aluminium is a potent toxicant in acidic soils. The present study was taken up to analyze the effects of Al on enzymes of nitrogen assimilation in excised bean (Phaseolus vulgaris) leaf segments so as to gain an insight of the mechanism involved. Supply of 0.001 to $0.1 \mathrm{mM} \mathrm{AlCl} \mathrm{H}_{3}$ to excised bean leaf segments affected the in vivo nitrate reductase activity differently in the presence of various inorganic nitrogenous compounds, being inhibited with $5 \mathrm{mM}$ ammonium nitrate and $10 \mathrm{mM}$ ammonium chloride but enhanced with $10 \mathrm{mM}$ potassium nitrate. Al effect with $50 \mathrm{mM} \mathrm{KNO} \mathrm{Karied}_{3}$ with time, showing an increased activity at shorter duration, but decreased at longer duration. Al effect on in vivo NRA was dependent upon the nitrate concentration, thus, inhibiting it at 0,1 and $50 \mathrm{mM} \mathrm{KNO}{ }_{3}$, while increasing at 2 and $10 \mathrm{mM}$. Further, saturating and non-saturating effects were observed in the absence and presence of Al. Al supply influenced the in vitro NRA also, being increased at $10 \mathrm{mM}$, but decreased at $50 \mathrm{mM} \mathrm{KNO}_{3}$. Supply of Al to excised leaf segments substantially inhibited the glutamate dehydrogenase activity in the absence as well as presence of $5 \mathrm{mM}$ $\mathrm{NH}_{4} \mathrm{NO}_{3}$ but increased the glutamate synthase activity. Inhibition of specific glutamate dehydrogenase activity by Al supply was also observed. However, specific glutamate synthase activity was increased in the presence of $\mathrm{NH}_{4} \mathrm{NO}_{3}$ only. The experiments demonstrated that effect of supply of aluminium on in vivo nitrate reductase activity depended upon nitrogenous source as well as nitrate concentration and it exerted reciprocal regulation of glutamate dehydrogenase and glutamate synthase activities, which depended upon $\mathrm{N}$ supply too.
\end{abstract}

\section{Keywords}

Aluminium Effects, Glutamate Dehydrogenase, Glutamate Synthase, Nitrate Reductase, Bean Leaves, Phaseolus vulgaris

\footnotetext{
${ }^{*}$ Corresponding author.
}

How to cite this paper: Gupta, P., Sarengthem, J., Dhamgaye, S. and Gadre, R. (2016) Differential Effect of Aluminium on Enzymes of Nitrogen Assimilation in Excised Bean Leaf Segments. Advances in Biological Chemistry, 6, $106-113$. 


\section{Introduction}

Aluminium (Al), one of the most abundant metals, is not regarded as an essential nutrient for plants, but low concentrations can sometimes increase plant growth or induce other desirable effects [1]. When applied along with ammonia, it has been reported to promote growth in tropical plants adapted to acid soils [2]. Beneficial effects of $\mathrm{Al}$ on plant growth have also been reported in Camellia sinensis [3], Miconia albican Steud [4] and Pinus radiata D. Don [5]. Aluminium is one of the most toxic metals for plant growth in acidic soil. Under acidic conditions, it exists as soluble and toxic monomeric $\mathrm{Al}^{3+}$ species [6]. Several phytotoxic effects of aluminium have been reported including the inhibition of root growth and nutrient uptake; however, the mechanism is not well understood [7]-[9]. Aluminium causes significant decline in the leaf area, fresh weight and dry weight [10]. It affects mitochondrial dysfunction, which leads to reactive oxygen species production, probably the key critical event in aluminium-induced inhibition of cell growth [11].

Nitrate reductase (NR, EC 1.6.6.1) is a substrate inducible key enzyme of nitrate assimilation. It is regulated by a number of nutritional and environmental factors [12]. Nitrate reductase activity is often correlated with the overall nitrogenous status of the system. Glutamate dehydrogenase (GDH, EC 1.4.1.3) forms a link between carbon and nitrogen metabolism. Further, the enzyme seems to be important in ammonia assimilation under stressful conditions [13]. Glutamate synthase (GOGAT, EC 1.4.1.14) plays a key role in maintaining appropriate levels of glutamate. Results of $\mathrm{Al}$ effects on nitrogen assimilation have been found to be inconsistent. Thus, in Sorghum, $\mathrm{Al}$ rapidly reduces $\mathrm{NO}_{3}^{-}$uptake and enhances $\mathrm{NH}_{4}^{+}$uptake so that total $\mathrm{N}$ uptake is almost unaffected [14], while it inhibits nitrate and ammonium uptake in maize [15]. In maize roots, Al induces anaplerotic GDH, while inhibiting glutamine synthetase (GS, EC 6.3.1.2). However, in leaves it does not influence GOGAT and GS activities [15]. Al effects on nitrate reductase activity (NRA) vary from inhibition to stimulation in different systems under different conditions [14] [16] [17]. In the present study, the effect of $\mathrm{Al}$ on enzymes of $\mathrm{N}$ assimilation in excised bean leaf segments is analyzed with an insight to gain information about the mechanism of $\mathrm{Al}$ effect on enzymes of nitrogen assimilation.

\section{Materials and Methods}

\subsection{Plant Material and Treatments}

Seeds of Phaseolus vulgaris cv. Rajmah purchased from a local dealer were surface sterilized with $0.1 \% \mathrm{HgCl}_{2}$ for 1 - 2 minutes followed by thorough washing with distilled water. The seedlings were raised in plastic pots containing acid washed sand for 7 - 8 days in continuous light of intensity $30 \mathrm{Wm}^{-2}$ supplied by fluorescent tubes at $28^{\circ} \mathrm{C} \pm 3^{\circ} \mathrm{C}$. They were watered with $1 / 2$ strength Hoagland's solution (pH 6.0) containing no nitrogen. For various treatments primary leaves from uniformly grown seedlings were cut into about $0.5 \times 0.5 \mathrm{~cm}$ segments and floated on 1/4 strength Hoagland's solution containing desired compounds, as mentioned in the tables, for required time period in continuous light supplied by fluorescent tubes.

\subsection{Enzymatic Analyses}

In vivo NRA was assayed by colorimetric estimation of nitrite according to the method of Srivastava [18]. In vitro NRA was extracted and assayed by the method of Stevens and Oaks [19]. Cytochrome c reductase activity in extract of NR was assayed spectrophotometrically by monitoring the change in absorbance at $550 \mathrm{~nm}$ according to procedure of Wallace and Johanson [20]. Glutamate dehydrogenase preparation was obtained according to the procedures described in Puranik and Srivastava [21] and the activity was assayed by monitoring the decrease in absorbance at $340 \mathrm{~nm}$ according to the method of Singh and Srivastava [22]. Glutamate synthase preparation was obtained and assayed for activity based upon the measurement of decrease in absorbance at $340 \mathrm{~nm}$ following the method described in Puranik and Srivastava [23]. The unit of enzyme activities of GDH and GOGAT is defined as nmoles of reduced nicitinamide adenine dinucleotide (NADH) oxidized per min. To calculate specific activity, the protein content of the preparations was estimated by Lowry's method [24] after precipitation with trichloro acetic acid.

Results expressed are the average values of at least four independent experiments with \pm SE. Difference between means obtained for various treatments was tested by Student's $t$ test at level of significance- $\mathrm{a}$ : $\mathrm{p}<0.05$, b: $\mathrm{p}<0.01$, c: $\mathrm{p}<0.001$. 


\section{Results}

\subsection{Al Effects on NRA}

Supply of 0.001 to $0.1 \mathrm{mM} \mathrm{AlCl}_{3}$ to excised bean leaf segments in the presence of $10 \mathrm{mM} \mathrm{KNO}_{3}$ gradually increased in vivo NRA (Table 1). While in presence of $5 \mathrm{mM} \mathrm{NH}_{4} \mathrm{NO}_{3}$ and $10 \mathrm{mM} \mathrm{NH} \mathrm{N}_{4} \mathrm{Cl}$ the enzyme activity was gradually decreased by $\mathrm{Al}$ supply (Table 1 ).

Supply of $0.1 \mathrm{mM} \mathrm{Al}$ in the presence of $50 \mathrm{mM} \mathrm{KNO}_{3}$ for short interval up to $4 \mathrm{~h}$ maintained a higher level of in vivo NRA over control ranging from $15 \%$ to $36 \%$ (Figure 1).

When leaf segments were treated with $\mathrm{Al}$ in presence of varying concentrations of $\mathrm{KNO}_{3}$, the in vivo NRA was inhibited in the absence of nitrate and at 1 and $50 \mathrm{mM} \mathrm{KNO}_{3}$ (Table 2). However, at 2 and $10 \mathrm{mM} \mathrm{KNO}_{3}$ the enzyme activity was increased by $\mathrm{Al}$ (Table 2). Further, to analyse uptake kinetics, a plot of $\mathrm{KNO}_{3}$ concentration vs in vivo NRA was constructed. It yielded non-saturating effect in the absence of Al, but saturating effect in the presence of $0.1 \mathrm{mM} \mathrm{Al}$ (Figure 2).

Treatment of leaf segments with $0.1 \mathrm{mM} \mathrm{Al}$ in the presence of $10 \mathrm{mM} \mathrm{KNO}_{3}$ caused an increase in total as well as specific in vitro activity of NR (Table 3). However, in the presence of $50 \mathrm{mM} \mathrm{KNO}_{3}$, the activity was decreased by Al. Aluminium supply caused a marginal decrease in cytochrome c reductase activity at $50 \mathrm{mM}$ $\mathrm{KNO}_{3}$ only (Table 3).

\subsection{Al Effects on GDH and GOGAT}

Supply of $0.1 \mathrm{mM} \mathrm{AlCl}_{3}$ to leaf segments inhibited the NADH-GDH activity significantly (Table 4). However,

Table 1. Effect of supply of $\mathrm{Al}$ on inducibility of in vivo nitrate reductase activity by different nitrogenous compounds in excised bean leaf segments.

\begin{tabular}{cccc}
\hline Treatment & \multicolumn{3}{c}{$\mathrm{NRA}_{\text {, }}{\mathrm{nmoles} \mathrm{NO}_{2} \mathrm{~h}^{-1} \cdot \mathrm{g}^{-1} \text { fr. wt. }}$} \\
\hline $\mathrm{AlCl}_{3}$ conc., $\mathrm{mM}$ & $\mathrm{KNO}_{3}, 10 \mathrm{mM}$ & $\mathrm{NH}_{4} \mathrm{NO}_{3}, 5 \mathrm{mM}$ & $597 \pm 79$ \\
0.000 & $1610 \pm 78$ & $1283 \pm 110$ & $(100)$ \\
& $(100)$ & $(100)$ & $520 \pm 94$ \\
0.001 & $1660 \pm 197$ & $1020 \pm 135$ & $(87)$ \\
& $(103)$ & $(80)$ & $481 \pm 44$ \\
0.010 & $1836 \pm 195$ & $1038 \pm 122$ & $(81)$ \\
& $(114)$ & $1040 \pm 152$ & $461 \pm 60$ \\
\hline
\end{tabular}

Leaf segments were floated on 1/4 strength Hoagland's solution containing the desired nitrogenous compounds in the presence of varying concentrations of $\mathrm{AlCl}_{3}$ for $24 \mathrm{~h}$ at continuous light intensity of $30 \mathrm{Wm}^{-2}$ and temperature $26^{\circ} \mathrm{C} \pm 2^{\circ} \mathrm{C}$.

Values relative to control are given in parentheses.

Table 2. Effect of supply of $\mathrm{Al}$ on in vivo NRA at varying concentrations of $\mathrm{KNO}_{3}$ in excised bean leaf segments.

\begin{tabular}{cccc}
\hline Treatment & \multicolumn{2}{c|}{ In vivo NRA, nmoles $\mathrm{NO}_{2} \mathrm{~h}^{-1} \cdot \mathrm{g}^{-1} \mathrm{fr} . \mathrm{wt}}$. & \\
\hline $\mathrm{KNO}_{3}$ conc., $\mathrm{mM}$ & $-\mathrm{Al}$ & $+\mathrm{Al}$ & \% Increase/Decrease \\
\hline 00 & $774 \pm 20$ & $606 \pm 31^{\mathrm{c}}$ & $22 \%$ Decrease \\
& $(100)$ & $(100)$ & $7 \%$ Decrease \\
01 & $957 \pm 99$ & $(147)$ & $9 \%$ Increase \\
& $(124)$ & $1242 \pm 112$ & $14 \%$ Increase \\
& $1134 \pm 82$ & $(205)$ & \\
& $(146)$ & $1827 \pm 148$ & $21 \%$ Decrease \\
\hline
\end{tabular}

Leaf segments were floated on $1 / 4$ strength Hoagland's solution containing the desired concentrations of $\mathrm{KNO}_{3}$ in the absence and presence of 0.1 $\mathrm{mM} \mathrm{AlCl}_{3}$ for $24 \mathrm{~h}$ at continuous light intensity of $30 \mathrm{Wm}^{-2}$ and temperature $26^{\circ} \mathrm{C} \pm 2^{\circ} \mathrm{C}$.

Values relative to control are given in parentheses.

Level of significance-c: $\mathrm{p}<0.001$. 


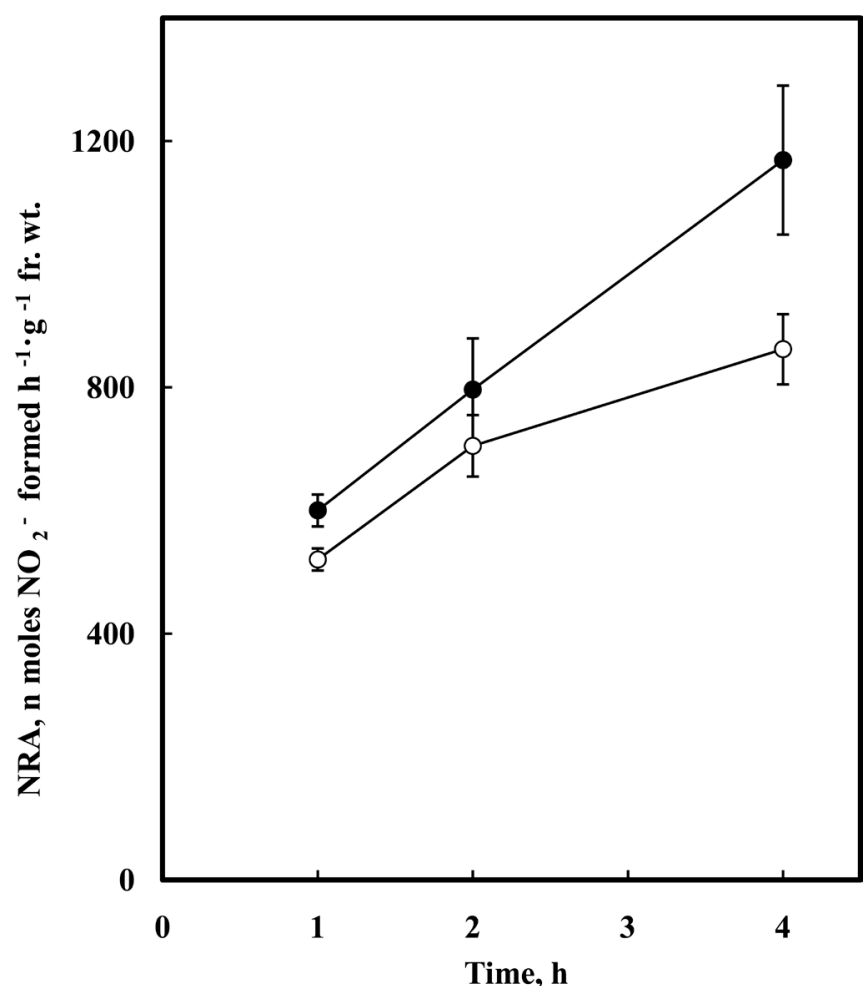

Leaf segments were floated on $1 / 4$ strength Hoagland's solution containing $50 \mathrm{mM} \mathrm{KNO}_{3}$ in the absence and presence of $0.1 \mathrm{mM} \mathrm{AlCl}_{3}$ for different time intervals at continuous light intensity of $30 \mathrm{Wm}^{-2}$ and temperature $26^{\circ} \mathrm{C} \pm 2^{\circ} \mathrm{C}$.

Symbols used: Open circles (०----०) -A; Closed circles $(\bullet----\bullet)+\mathrm{Al}, 0.1 \mathrm{mM}$.

Figure 1. Effect of supply of $\mathrm{Al}$ on in vivo NRA at $50 \mathrm{mM} \mathrm{KNO}_{3}$ in excised bean leaf segments at different time intervals.

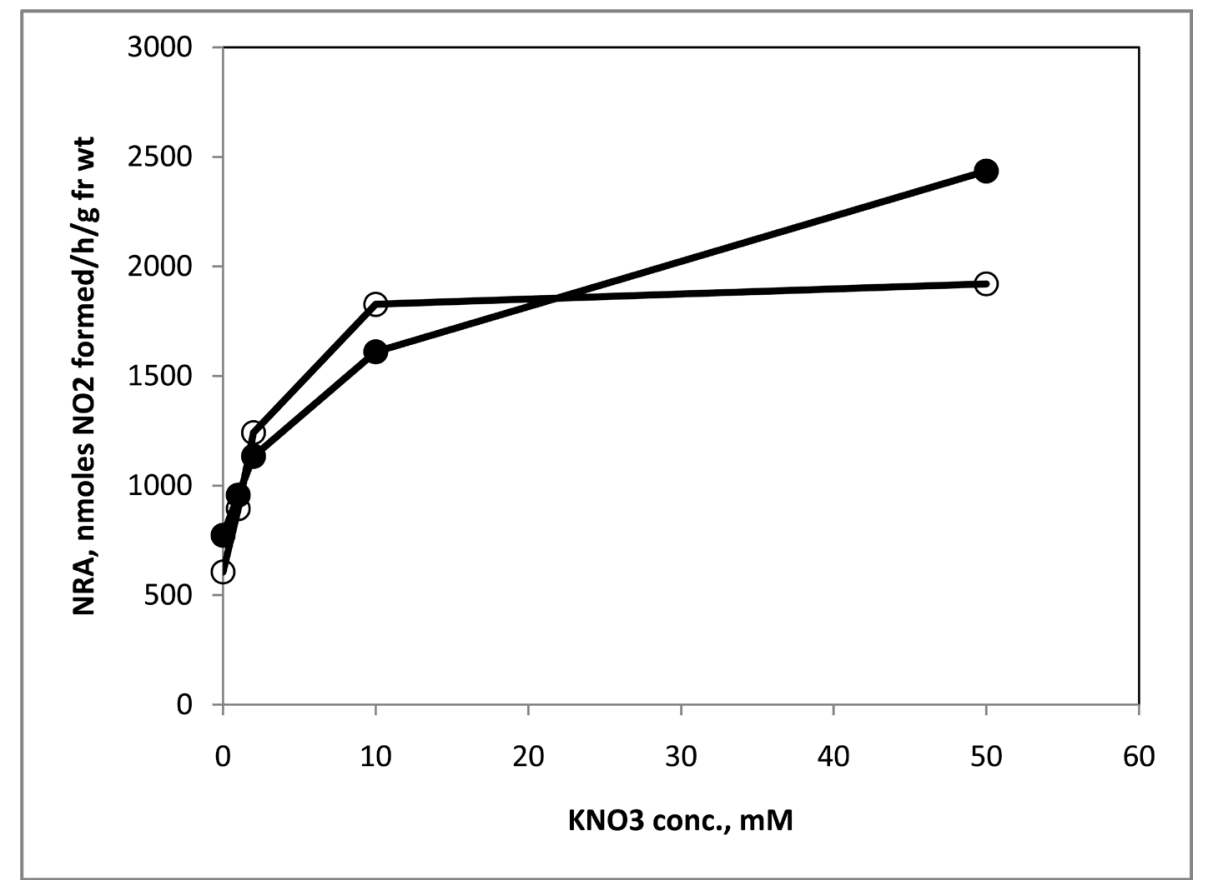

Leaf segments were floated on $1 / 4$ strength Hoagland's solution containing the desired concentrations of $\mathrm{KNO}_{3}$ in the absence and presence of $0.1 \mathrm{mM} \mathrm{AlCl} 3$ for $24 \mathrm{~h}$ at continuous light intensity of $30 \mathrm{Wm}^{-2}$ and temperature $26^{\circ} \mathrm{C} \pm 2^{\circ} \mathrm{C}$.

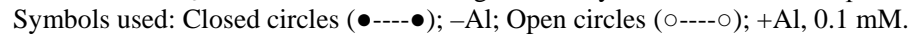

Figure 2. Effect of supply of $\mathrm{Al}$ on in vivo NRA at varying concentrations of $\mathrm{KNO}_{3}$ in excised bean leaf segments. 
Table 3. Effect of supply of $\mathrm{Al}$ on in vitro nitrate reductase and cytochrome c reductase activities in excised bean leaf segments.

\begin{tabular}{cccc}
\hline \multirow{2}{*}{ Treatment } & \multicolumn{2}{c}{ In vitro NRA } & Cyt c reductase \\
\cline { 2 - 4 } & nmoles $\mathrm{NO}_{2} \mathrm{~h}^{-1} \cdot \mathrm{g}^{-1}$ fr. wt. & nmoles $\mathrm{NO}_{2} \mathrm{~h}^{-1} \cdot \mathrm{mg}^{-1}$ protein & $\Delta \mathrm{A}_{550} \mathrm{~min}^{-1} \cdot \mathrm{g}^{-1} \mathrm{fr}$. wt. \\
\hline $\mathrm{KNO}_{3}, 10 \mathrm{mM}$ & $664 \pm 149$ & $20 \pm 4$ & $0.882 \pm 0.067$ \\
& $(100)$ & $(100)$ & $(100)$ \\
$\mathrm{KNO}_{3}, 10 \mathrm{mM}+\mathrm{AlCl}_{3}, 0.1 \mathrm{mM}$ & $874 \pm 289$ & $25 \pm 8$ & $(125)$ \\
$\mathrm{KNO}_{3}, 50 \mathrm{mM}$ & $(132)$ & $38 \pm 6$ & $(96)$ \\
& $1239 \pm 220$ & $(100)$ & $0.900 \pm 0.035$ \\
$\mathrm{KNO}_{3}, 50 \mathrm{mM}+\mathrm{AlCl}_{3}, 0.1 \mathrm{mM}$ & $995 \pm 442$ & $27 \pm 9$ & $(100)$ \\
\end{tabular}

Leaf segments were floated on $1 / 4$ strength Hoagland's solution containing 10 and $50 \mathrm{mM} \mathrm{KNO}_{3}$ in the absence and presence of $0.1 \mathrm{mM} \mathrm{AlCl}_{3}$ for 24 $\mathrm{h}$ at continuous light intensity of $30 \mathrm{Wm}^{-2}$ and temperature $26^{\circ} \mathrm{C} \pm 2^{\circ} \mathrm{C}$.

Values relative to control are given in parentheses.

Table 4. Effect of supply of Al on NADH-GDH and NADH-GOGAT activity in excised bean leaf segments.

\begin{tabular}{lllll}
\hline & NADH-GDH activity & & \multicolumn{2}{l}{ NADH-GOGAT activity } \\
Treatment & Units ml ${ }^{-1}$ Enzyme & Units $\mathrm{mg}^{-1}$ & Units ml & ${\text { Units } \mathrm{mg}^{-1}}^{-1}$ \\
& & Protein & Enzyme & Protein $^{-1}$ \\
Control (-N) & $63.1 \pm 6.3$ & $34.2 \pm 3.9$ & $8.4 \pm 2.4$ & $4.4 \pm 1.3$ \\
& $(100)$ & $(100)$ & $(100)$ & $(100)$ \\
$\mathrm{AlCl}_{3}, 0.1 \mathrm{mM}$ & $31.6 \pm 1.9^{\mathrm{b}}$ & $19.7 \pm 2.9^{\mathrm{a}}$ & $14.6 \pm 5.2$ & $4.2 \pm 1.6$ \\
& $(50)$ & $(58)$ & $(174)$ & $(96)$ \\
\hline
\end{tabular}

Leaf segments were floated on $1 / 4$ strength Hoagland's solution in either, the absence $\left(-\mathrm{N}\right.$ Control) or presence of $0.1 \mathrm{mM}$ AlCl $\mathrm{for}_{3} 18 \mathrm{~h}$ at continuous light intensity of $40 \mathrm{Wm}^{-2}$ and temperature $26^{\circ} \mathrm{C} \pm 2^{\circ} \mathrm{C}$ inside "Newtronics" growth chamber.

Values relative to control are given in parentheses.

Level of significance-a: $\mathrm{p}<0.05$, b: $\mathrm{p}<0.01$.

Table 5. Effect of supply of Al on NADH-GDH and NADH-GOGAT activity in excised bean leaf segments in presence of 5 $\mathrm{mM} \mathrm{NH}_{4} \mathrm{NO}_{3}$.

\begin{tabular}{ccccc}
\hline \multirow{2}{*}{ Treatment } & \multicolumn{2}{c}{ NADH-GDH activity } & \multicolumn{2}{c}{ NADH-GOGAT activity } \\
& Units ml $^{-1}$ Enzyme & $\begin{array}{c}\text { Units mg }^{-1} \\
\text { Protein }\end{array}$ & $\begin{array}{c}\text { Units } \mathrm{ml}^{-1} \\
\text { Enzyme }\end{array}$ & $\begin{array}{c}\text { Units mg }^{-1} \\
\text { Protein }\end{array}$ \\
\cline { 2 - 5 } Control $(+\mathrm{N})$ & $96.3 \pm 11.0$ & $65.8 \pm 7.4$ & $15.3 \pm 3.2$ & $8.3 \pm 1.9$ \\
& $(100)$ & $(100)$ & $(100)$ & $(100)$ \\
$\mathrm{AlCl}_{3}, 0.1 \mathrm{mM}$ & $19.7 \pm 2.2^{\mathrm{c}}$ & $26.3 \pm 2.9^{\mathrm{c}}$ & $19.8 \pm 6.0$ & $11.2 \pm 3.1$ \\
& $(20)$ & $(40)$ & $(129)$ & $(135)$ \\
\hline
\end{tabular}

Leaf segments were floated on $1 / 4$ strength Hoagland's solution in either, the absence (+N Control) or presence of $0.1 \mathrm{mM} \mathrm{AlCl}_{3}$ for $18 \mathrm{~h}$ at continuous light intensity of $40 \mathrm{Wm}^{-2}$ and temperature $26^{\circ} \mathrm{C} \pm 2{ }^{\circ} \mathrm{C}$ inside "Newtronics" growth chamber.

Values relative to control are given in parentheses.

Level of significance-c: $\mathrm{p}<0.001$.

Al supply increased the NADH-GOGAT activity substantially (Table 4). The specific activity of NADH-GDH was also decreased due to inclusion of $\mathrm{Al}$, but that of NADH-GOGAT remained unaltered.

When leaf segments were treated with $0.1 \mathrm{mM} \mathrm{AlCl}_{3}$ containing $5 \mathrm{mM} \mathrm{NH}_{4} \mathrm{NO}_{3}$, severe inhibition of NADHGDH activity was observed (Table 5). However, NADH-GOGAT activity, in the presence of $\mathrm{NH}_{4} \mathrm{NO}_{3}$, was increased due to Al supply (Table 5). During Al supply, the specific activity of NADH-GDH was decreased while that of NADH-GOGAT increased.

\section{Discussion}

\subsection{Al Effects on NRA}

The results demonstrate a differential effect of Al supply on in vivo nitrate reductase activity in bean leaf segments depending upon the nitrogenous compound included and nitrate concentration as well. The enzyme activity is increased by $\mathrm{Al}$ in the presence of $\mathrm{KNO}_{3}$, but decreased with $\mathrm{NH}_{4} \mathrm{NO}_{3}$ as well as $\mathrm{NH}_{4} \mathrm{Cl}$ (Table 1). Thus, it seems that $\mathrm{Al}$ decreases $\mathrm{NH}_{4}^{+}$availability, while increases $\mathrm{NO}_{3}^{-}$availability for induction of NRA. However, decreased uptake of $\mathrm{NO}_{3}^{-}$and $\mathrm{NH}_{4}^{+}$both by $\mathrm{Al}$ in maize roots has been reported [15]. Thus, it is likely that 
NR inducibility in the presence of $\mathrm{Al}$ depends upon $\mathrm{NO}_{3}^{-}$uptake. In cucumber roots and soybean seedlings, aluminium at varying concentration has been reported to affect nitrate uptake-being increased at lower concentration, but decreasing at higher concentration [25] [26] and at very high concentration causing nitrate efflux [25]. The effect of $\mathrm{Al}$ on nitrate uptake depends on duration of exposure too. Thus, supply of $\mathrm{Al}$ for longer durations has been reported to reduce it [27] [28], while short-term supply induced it [29]. In the present study, the NRA was inhibited by $\mathrm{Al}$ in the presence of 1 and $50 \mathrm{mM} \mathrm{KNO}_{3}$, but it was increased by Al with 2 and $10 \mathrm{mM}$ $\mathrm{KNO}_{3}$ (Table 2). Moreover, $\mathrm{Al}$ supplied in the presence of $50 \mathrm{mM}$ nitrate upto $4 \mathrm{~h}$ increased the NRA (Figure 1) but the activity was decreased at $24 \mathrm{~h}$ (Table 2).

Plants have multiple nitrate carriers with distinct kinetic properties and regulation. Thus, there are at least three distinct $\mathrm{NO}_{3}^{-}$uptake systems, two of which have a high affinity for $\mathrm{NO}_{3}^{-}$, while the third has a low affinity. Also, the high-affinity transport system displays Michaelis-Menten kinetics saturating at $0.2-0.5 \mathrm{mM}$ nitrate. However, the low-affinity transport system operates at concentrations above $0.5 \mathrm{mM}$, and usually displays non-saturating uptake kinetics. In the present study, the dependence of $\mathrm{Al}$ effect on nitrate concentration suggest that high affinity active transport system of $\mathrm{NO}_{3}^{-}$uptake appears to be inhibited by $\mathrm{Al}$, as inhibitory effect of $\mathrm{Al}$ on NRA is observed up to $1 \mathrm{mM} \mathrm{KNO}_{3}$ (Table 2) and exhibit saturating effect (Figure 2). Al also influences passive diffusion through ion channels negatively, as it inhibited NRA at super-saturating concentration, $50 \mathrm{mM}$ $\mathrm{KNO}_{3}$ (Table 2). On the other hand, low affinity active transport system appears to be activated by $\mathrm{Al}$, as $\mathrm{Al}$ increases NRA at $2-10 \mathrm{mM} \mathrm{KNO}_{3}$ (Table 2). Further, direct effect of Al on NRA is also likely, as in vitro total and specific activities both are altered by Al supply. However, cytochrome c reductase activity of the preparation remains unaltered (Table 3) indicating that the terminal nitrate reductase is likely to be affected rather than NADH-dehydrogenase activity.

\subsection{Al Effects on GDH and GOGAT}

Reciprocal regulation of NADH-GDH and NADH-GOGAT during supply of $\mathrm{Al}$ with and without $\mathrm{NH}_{4} \mathrm{NO}_{3}$ in excised bean leaf segments was demonstrated. Thus, Al stress severely inhibits NADH-GDH activity but activates NADH-GOGAT activity (Table 1) and seems to favour GS/GOGAT pathway for ammonia assimilation. Although, two enzymes of ammonia assimilation have been reported to be reciprocally influenced by $\mathrm{Cd}$ and glutathione also, but increased NADH-GDH activity by Cd indicated its possible role in ammonia assimilation during metallic stress [30]. In the present study, inhibition of NADH-GDH activity by Al does not appear to result due to overall decrease in metabolic activities, as specific activity of enzyme is also decreased by Al supply (Table 4). However, elevated deaminating GDH activity by $\mathrm{Al}$ in maize roots was shown to be indicative of metabolic changes associated with plant senescence [15].

In the present investigation, the inhibitory effect of Al on NADH-GDH activity is dependent on the supply of nitrogen in the incubation medium. Thus, stronger inhibition of enzyme activity results in the presence of $\mathrm{NH}_{4} \mathrm{NO}_{3}$, as $\mathrm{N}$-supply increases the activity in the absence of Al only (Table 4 and Table 5). However, specific activity was increased by $\mathrm{N}$-supply in both, the absence and presence of Al (Table 4 and Table 5). Under Al stress, reduced activity of glutamate dehydrogenase has also been reported in soybean root nodules [31]. Decreased uptake of $\mathrm{NO}_{3}^{-}$and $\mathrm{NH}_{4}^{+}$by $\mathrm{Al}$ in maize roots has been reported [15]. Hence, decrease in NADHGDH activity due to Al supply seems to result because of reduced uptake of inorganic nitrogen in particular $\mathrm{NH}_{4}^{+}$. Further, $\mathrm{Al}$ treatment in wheat has been reported to inhibit $\mathrm{Ca}^{++}$uptake resulting in reduced $\mathrm{Ca}^{++}$influx [32]. So, reduced activity of enzyme due to $\mathrm{Ca}^{++}$depletion is likely, as it is stimulatory for GDH [33]. Inhibition of GDH activity and no change in GS and GOGAT activities by Al treatment has been observed in maize leaves [15]. However, inhibition of GS and NADH-GOGAT activities by Al supply has been reported in soybean root nodules [31]. In the present study, The NADH-GOGAT activity is increased by N-supply in the absence as well as presence of $\mathrm{Al}$, being more prominent for the former (Table 4 and Table 5). Decreased asparagine/glutamine ratio by Al treatment [34] and increased in vitro GS activity by Al III complex [35] have been reported. Hence, $\mathrm{Al}$ treatment may enhance glutamine level thus increasing NADH-GOGAT activity. Role of GS/GOGAT pathway in ammonia assimilation during $\mathrm{Al}$ supply is suggested.

\subsection{Conclusion}

Effect of aluminium supply on in vivo NRA depends upon nitrogenous source as well as nitrate concentration and it exerts reciprocal regulation of NADH-GDH and NADH-GOGAT activities, which depends upon N supply too. 


\section{References}

[1] Foy, C.D. (1983) The Physiology of Plant Adaptation to Metal Stress. Iowa State Journal of Research, 57, $355-391$.

[2] Watanabe, T., Osaki, M. and Tadana, T. (1998) Effect of Nitrogen Source and Aluminium on Growth of Tropical Tree Seedlings Adapted to Low pH Soil. Soil Science \& Plant Nutrition, 44, 655-666. http://dx.doi.org/10.1080/00380768.1998.10414489

[3] Konishi, S., Miyamoto, S. and Taki, T. (1985) Stimulatory Effects of Aluminium on Tea Plants Grown under Low and High Phosphorus Supply. Soil Science \& Plant Nutrition, 31, 361-368. http://dx.doi.org/10.1080/00380768.1985.10557443

[4] Haridasan, M. (1988) Performance of Miconia albicans (SW.) Triana, an Aluminium-Accumulating Species, in Acidic and Calcareous Soils. Communications in Soil Science and Plant Analysis, 19, 1091-1103. http://dx.doi.org/10.1080/00103628809367997

[5] Huang, J. and Bachelard, E.P. (1993) Effects of Aluminium on Growth and Cation Uptake in Seedlings of Eucalyptus mannifera and Pinus radiata. Plant Soil, 149, 121-127. http://dx.doi.org/10.1007/BF00010769

[6] Kinraide, T.B. (1991) Identity of the Rhizotoxic Aluminium Species. Plant Soil, 134, 167-178. http://dx.doi.org/10.1007/978-94-011-3438-5_80

[7] Delhaize, E. and Ryan, P.R. (1995) Aluminium Toxicity and Tolerance in Plants. Physiologia Plantarum, 170, 315321.

[8] Kochian, L.V. (1995) Cellular Mechanisms of Aluminium Toxicity and Resistance in Plants. Annual Review of Plant Physiology and Plant Molecular Biology, 46, 237-260. http://dx.doi.org/10.1146/annurev.pp.46.060195.001321

[9] Rout, G.R., Samantray, S. and Das, P. (2001) Aluminium Toxicity in Plants: A Review. Agronomie, 21, 3-21. http://dx.doi.org/10.1051/agro:2001105

[10] Neogy, M., Dutta, J., Roy, A.K. and Mukharji, S. (2002) Studies on Phytotoxic Effect of Aluminium on Growth and Some Morphological Parameters of Vigna radiata L. Wilczek. Journal of Environmental Biology, 234, 411-416

[11] Yamamoto, Y., Kobayashi, Y., Rama Devi, S., Rikiishi, S. and Matsumoto, H. (2002) Aluminium Toxicity Is Related with Mitochondrial Dysfunction and the Production of Reactive Oxygen Species in Plant Cells. Plant Physiology, 128, 63-72. http://dx.doi.org/10.1104/pp.010417

[12] Srivastava, H.S. (1980) Regulation of Nitrate Reductase in Higher Plants. Phytochemistry, 19, 725-733. http://dx.doi.org/10.1016/0031-9422(80)85100-4

[13] Srivastava, H.S. and Singh, R.P. (1987) Role and Regulation of L-Glutamate Dehydrogenase Activity in Higher Plants. Phytochemistry, 26, 597-610. http://dx.doi.org/10.1016/S0031-9422(00)84749-4

[14] Keltjens, W.G. (1988) Short-Term Effects of Al on Nutrient Uptake, H+ Efflux, Root Respiration and Nitrate Reductase Activity of Two Sorghum Genotypes Differing in Al-Susceptibility. Communications in Soil Science and Plant Analysis, 19, 1155-1163. http://dx.doi.org/10.1080/00103628809368002

[15] Purcino, A.A.C., Alves, V.M.A., Parentoni, S.N., Belele, C.N. and Loguercio, L.L. (2003) Aluminium Effects on Nitrogen Uptake and Assimilating Enzymes in Maize Genotypes with Contrasting Tolerance to Aluminium Toxicity. Journal of Plant Physiology, 26, 31-61.

[16] Cumming, J.R. (1990) Nitrogen Source Effects on Al Toxicity in Nonmycorrhizal and Mycorrhizal Pitch Pine (Pinus rigida) Seedlings. II. Nitrate reduction and $\mathrm{NO}_{3}{ }^{-}$Uptake. Canadian Journal of Botany, 68, 2653-2659. http://dx.doi.org/10.1139/b90-335

[17] Lidon, F.C., Ramahlo, J.C. and Barreiro, M.G. (1998) Aluminium Toxicity Modulates Nitrate to Ammonia Reduction. Photosynthetica, 35, 213-222. http://dx.doi.org/10.1023/A:1006906722469

[18] Srivastava, H.S. (1975) Distribution of Nitrate Reductase in Bean Seedlings. Plant and Cell Physiology, 16, $995-999$.

[19] Stevens, D.L. and Oaks, A. (1973) The Influence of Nitrate in Induction of Nitrate Reductase in Maize Roots. Canadian Journal of Botany, 51, 1255-1258. http://dx.doi.org/10.1139/b73-157

[20] Wallace, W. and Johnson, C.B. (1978) Nitrate Reductase and Soluble Cytochrome $c$ Reductase(s) in Higher Plants. Plant Physiology, 61, 748-752. http://dx.doi.org/10.1104/pp.61.5.748

[21] Puranik, R.M. and Srivastava, H.S. (1986) Sensitivity to DTNB of NADH-Glutamate Dehydrogenase from the Leaves of Bean Seedlings. Phytochemistry, 25, 803-806. http://dx.doi.org/10.1016/0031-9422(86)80005-X

[22] Singh, R.P. and Srivastava, H.S. (1983) Regulation of Glutamate Dehydrogenase Activity by Amino Acids in Maize Seedling. Physiologia Plantarum, 57, 549-554. http://dx.doi.org/10.1111/j.1399-3054.1983.tb02784.x

[23] Puranik, R.M. and Srivastava, H.S. (1990) Increase in NADH-Glutamate Synthase Activity in Bean Leaf Segments by Light. Current Science, 59, 1001-1004.

[24] Lowry, O.H., Roseborough, N.J., Farr, A.L. and Randall, R.J. (1951) Protein Measurement with the Folin-Phenol Rea- 
gent. The Journal of Biological Chemistry, 193, 265-275.

[25] Jerzykiewicz, J. (2001) Aluminium Effect on Nitrate Assimilation in Cucumber (Cucumis sativus L.) Roots. Acta Physiologiae Plantarum, 23, 213-219. http://dx.doi.org/10.1007/s11738-001-0011-3

[26] Rufty, T.W., MacKown, C.T., Lazof, D.B. and Carter, T.E. (1995) Effects of Aluminium on Nitrate Uptake and Assimilation. Plant, Cell \& Environment, 18, 1325-1331. http://dx.doi.org/10.1111/j.1365-3040.1995.tb00192.x

[27] Fleming, A.L. (1983) Ammonium Uptake by Wheat Varieties Differing in Al Tolerance. Agronomy Journal, 75, 726730. http://dx.doi.org/10.2134/agronj1983.00021962007500050003x

[28] Jarvis, S.C. and Hatch, D.J. (1986) The Effects of Low Concentrations of Aluminium on the Growth and Uptake of Nitrate-N by White Clover. Plant and Soil, 95, 43-55. http://dx.doi.org/10.1007/BF02378851

[29] Nichol, B.E., Oliviera, L.A., Glass, A.D.M. and Siddiqi, M.Y. (1993) The Effects of Aluminium on Influx of Calcium, Potassium, Ammonium, Nitrate, and Phosphate in a Aluminium-Sensitive Cultivar of Barley (Hordeum vulgare L.). Plant Physiology, 101, 1263-1266.

[30] Jain, M. and Gadre, R. (1998) Effect of Cadmium on NADH-Glutamate Dehydrogenase and NADH-Glutamate Synthase Activities in Excised Bean Leaf Segments: Role of Glutathione. Indian Journal of Experimental Biology, 36, 625-627.

[31] Balestrasse, K.B., Gallego, S.M. and Tomaro, M.L. (2006) Aluminium Stress Affects Nitrogen Fixation and Assimilation in Soybean (Glycine max L.). Plant Growth Regulation, 48, 271-281.

[32] Ryan, P.R. and Kochian, L.V. (1993) Interaction between Aluminium Toxicity and Calcium Uptake at the Root Apex in Near-Isogenic Lines of Wheat (Triticum aestivum L.) Differing in Aluminium Tolerance. Plant Physiology, 102, 975-982.

[33] Kindt, R., Pahlic, E. and Rasched, I. (1980) Glutamate Dehydrogenase from Peas: Isolation, Quaternary Structure, and Influence of Cations on Activity. European Journal of Biochemistry, 112, 533-540. http://dx.doi.org/10.1111/j.1432-1033.1980.tb06116.x

[34] Gomes, M.M.S., Cambria, J., Sant'anna, R. and Estevao, M.M. (1985) Aluminium Effects on Uptake and Translocation of Nitrogen in Sorghum. Journal of Plant Nutrition, 8, 457-465. http://dx.doi.org/10.1080/01904168509363360

[35] Kertsez, S., Fabian, A., Zsoldos, F., Vashegyi, A., Labadi, I., Bona, L. and Pecsvaradi, A. (2002) Changes in Glutamate Synthetase Activity in Presence of Aluminium Complexes. Acta Biologica Szegediensis, 45, 103-104. 